\title{
The Role Of Brand Image In Mediating Service Quality And Promotion Towards Decisions To Buy Car On Credit In The Covid-19 Period (Study Case At Pt Maybank Indonesia Finance Dki Jakarta And Tangerang Branch)
}

\author{
Saparso $^{1}$, Soegeng Wahyoedi ${ }^{2}$, Santoso ${ }^{3 *}$ \\ ${ }^{1,2,3}$ Faculty of Economic and Business, Krida Wacana Christian University \\ Corresponding Author: \\ Email: santosowangsa2@gmail.com
}

\begin{abstract}
.
This study discusses the role of brand image in mediating service quality and promotion of car purchase decisions on credit during the Covid-19 period at PT Maybank Indonesia Finance. This research was conducted by using the probability sampling method with the type of simple random sampling. Researchers distributed questionnaires to 100 Maybank Finance consumer respondents in DKI Jakarta and Tangerang. Data analysis using Smart PLS analysis. The results of the analysis conclude that service quality has a positive and significant influence on purchasing decisions. It can be said, good service quality will affect the decision to buy a car on credit at Maybank Finance. The promotion has a positive and significant influence on purchasing decisions. It can be said that the company's promotions will influence the decision to purchase a car on credit at Maybank Finance. Service quality has a positive and significant influence on brand image. Good service quality will form a good brand image in the minds of consumers. The promotion has a positive and significant influence on brand image. If the promotion is increasing, it will affect the company's brand image. Brand image has a positive and significant influence on purchasing decisions. A good brand image will influence the decision to buy a car on credit at Maybank Finance. Brand image is also proven to have a role in mediating service quality on purchasing decisions.
\end{abstract}

Keywords: Brand Image, Service Quality, Promotion, Purchasing Decision

\section{INTRODUCTION}

The development of world transportation is increasingly rapid. People are required to use transportation as a means to meet the needs of life. Cars are no longer a luxury and a tertiary need but have turned into a secondary need. Even a car is a vehicle that is a top priority to have. The need for car transportation encourages people to fulfill it quickly (Devina and Rokhyadi, 2019). Capital problems often constrain people who need a car, so they need a financing/leasing company. Plus the current situation. The pandemic period is due to the Covid 19 disease, which also affects the community's economic condition. The financing company enters as a service provider that aims to finance the purchase of a car in installments according to the period and interest that has been agreed upon by the company.PT. Maybank Indonesia Finance is one of the car loan financing companies in Indonesia that is currently developing. This company was established in 1991 which was formerly known as PT. BII Finance Center (BII Finance), but in 2015 changed its name to PT. Maybank Indonesia Finance. PT. Bank Maybank Indonesia Tbk owns Maybank Finance is $99.99 \%$ and is owned by employee cooperatives at $0.01 \%$. Following the business license of new and used car financing institutions and 2014, Maybank Finance expanded its business by penetrating the financing of heavy equipment and industrial machinery.

Table 1. Car Credit Sales Achievement Recap - New Car Maybank Indonesia Finance (Year 2018 - 2020)

\begin{tabular}{|c|c|c|c|c|}
\hline Year & $\begin{array}{c}\text { Unit } \\
\text { Financing }\end{array}$ & $\begin{array}{c}\text { Unit Growth } \\
(\%)\end{array}$ & $\begin{array}{c}\text { Financing } \\
\text { Nominal }\end{array}$ & $\begin{array}{c}\text { Financial Nominal } \\
\text { Growth (\%) }\end{array}$ \\
\hline 2018 & 47.478 & $0 \%$ & $9.737 \mathrm{M}$ & $0 \%$ \\
\hline 2019 & 45.263 & $-4,66 \%$ & $9.429 \mathrm{M}$ & $-3,16 \%$ \\
\hline 2020 & 23.722 & $-47,59 \%$ & $5.334 \mathrm{M}$ & $-43,42 \%$ \\
\hline
\end{tabular}

Source: www.maybankfinance.co.id (2021) 
This research was conducted at PT Maybank Indonesia Finance, where at this time, the Brand Image of Maybank Finance itself in the Market has not been so embedded in the minds of consumers who are still more familiar with other financing companies under the auspices of Private Banks which are well known in Indonesia which are still strong. Apart from that, the quality of service is also an internal factor of the company that must be improved, wherein the financing company, service quality is one of the main factors so that the number of complaints that come in from consumers must be responded to corrected immediately. The Promotion Strategy carried out by PT Maybank Indonesia Finance is currently still less effective where information about the Maybank Finance Promo often does not reach the Consumers.

\section{Service Quality}

A service is any action or activity that one party can offer to another, which is essentially intangible and does not result in the ownership of anything. Its production may or may not be linked to a single physical product (Kotler and Keller, 2016). According to A. Zeithaml (2009), service quality is: "Service quality focuses specifically on dimensions of service. Based on this view, perceived service quality is a component of customer satisfaction. Service quality is a focused evaluation that reflects the customer perception of reliability, assurance, responsiveness, empathy, and tangibles. Meanwhile, Kotler and Armstrong (2018) define service quality as "the customer's judgment about an entity's overall excellence or superiority and suggest that perceived quality." According to Tjiptono and Chandra (2016), service quality is "all efforts to meet consumer needs and desires as well as the accuracy of delivery in balancing consumer expectations."

Service quality plays an essential role in marketing all products/services and is especially important in many industries as it is the most effective differentiator for several products. Once market leaders based on technology or low price, companies now have to compete based on quality and customer service. Service quality is a measure of how well the level of service provided can meet customer expectations. Based on this definition, service quality can be realized through the fulfillment of customer needs and desires and the accuracy of delivery to balance customer expectations. In the research of Wahyoedi et al. (2021), it is said that service quality and innovation are two elements that can form a company's competitive advantage. Service quality is something that meets the expectations of consumers, and when consumer expectations are achieved, consumers can become loyal to these services (Wahyoedi \& Winoto, 2018).

\section{Promotion}

According to Susanto (2016), promotion is defined as persuading people to accept products, concepts, and ideas. According to Budianto (2015), promotion is a communication of information between sellers and buyers that aims to change the attitudes and behavior of buyers, who previously did not know to become familiar so that they buy and remember the product.Kotler and Keller (2016) sales promotion is a short-term incentive to encourage purchasing or selling a product or service. The existence of promotions aims to attract consumers to try new products, lure consumers to leave competing products or make consumers leave mature products, or withhold or reward loyal consumers.

Alma (2016) states that promotion is a type of communication that provides an explanation that convinces potential consumers about goods and services. Similarly, what is stated by Harman Malau (2017) that: "Promotion is a form of direct persuasion through the use of various incentives that can be arranged to stimulate product purchases immediately and / or increase the amount purchased by customers and make consumers satisfied so that they make repurchases." According to Kotler and Armstrong (2018), it is different, which states that "Promotion means activities that communicate the merits of the product and persuade target customers to buy it." According to Abdul Manap (2016), marketers communicate with potential audiences, and promotion is an effort made by marketers. Communication is a process of sharing an audience's ideas, information, or feelings.

According to Lupiyoadi (2014), several factors must be considered in promotion, including the following:

1. Identify the target audience first. This is related to market segmentation

2. Define promotion objectives. Is it to inform, influence, or to remind? 
3. Development of the message delivered. This relates to the content of the message (what to convey), the structure of the message (how to convey the message logically), the style of the message (creating strong language), and the source of the message (who should deliver).

Based on the understanding conveyed by the experts above, promotion is an activity in the field of marketing, which is a communication carried out by the company to prospective customers or prospective buyers that includes news, persuades, and influences everything about products or services produced for consumers. These activities aim to increase sales volume by attracting consumers' interest in making purchasing decisions at the company.

\section{Brand Image}

From a product or service, a brand (brand) can be born if the product, according to consumer perception, has a functional advantage (available brand), creates associations and images that consumers want (brand image), and evokes specific experiences when consumers interact with them (experiential brands). Customers' relationship to a brand will be stronger if it is based on many experiences or appearances to communicate it so that a brand image will be formed. A good brand image will encourage to increase sales volume and corporate image According to Kotler and Keller (2016), Brand Image is the perception and beliefs held by consumers, as reflected associations that are stored and embedded in the memory or memory of customers, which are always remembered the first time they hear the slogan and are embedded in the minds of consumers.

Supriyanto and Ernawaty (2010) state that brand image is the perception of a brand associated with market attitudes, including the level of preference (brand preference: preference compared to other products/services) and perceived benefits when using it later.Meanwhile, according to Peter and Olson (2009, in Pradita and Sitio, 2020), Defining brand image as consumer perceptions and preferences of a brand is reflected in various brand associations that exist in consumers' memories. Amitay et al. (2020) state that purchase Intention is a type of decision-making that studies. The reasons for buying a particular brand by customers. From the explanation above, it can be concluded that the notion of brand image is a collection of various kinds of brands formed and remembered by consumers. For a brand image to function, it must be conveyed through every available means of communication and brand contact.

\section{Purchasing Decision}

Consumer behavior is about what is bought or consumed by consumers and where, how habits, and under what conditions the products and services are purchased. According to Kotler and Keller (2016), Purchase decisions are "consumer decisions regarding preferences for brands in the choice set." Consumers can form an intention to buy the most preferred brand. However, two factors can be between purchase intention and purchase decision: attitude and unanticipated situational factors.Meanwhile, according to Tjiptono (2015), the purchase decision is "a process where consumers recognize the problem, seek information about a particular product or brand and evaluate how well each alternative can solve the problem, which then leads to a purchase decision."According to Peter and Olson (2009, in Pradita and Sitio, 2020), the purchase decision is the process of combining knowledge to evaluate two or more alternative behaviors and choose one of them. Setiadi (2013) said that the decisions taken by consumers could be referred to as problem-solving. In the decision-making process, consumers have a goal or behavior they want to achieve these goals.

This way, it can help solve the problem. Furthermore, it is explained that problem-solving is a continuous reciprocal flow between environmental factors, cognitive and affective processes, and behavioral actions. The first stage is understanding the problem. Then there is an evaluation of the existing alternatives, and the most appropriate action is selected. In the next stage, the purchase is expressed in actions that ultimately the goods selected or appointed will be used, and consumers will re-evaluate their decisions.From some of the meanings of decision-making described above, it can be concluded that purchasing decisions are a process of making decisions about purchases that will determine whether or not the purchase is purchased, which begins with an awareness of fulfillment or desire. Based on the description above, the formulation of the problem in this study are:

1. Does service quality influence the decision to purchase a car on credit at Maybank Finance? 
2. Does promotion influence the decision to purchase a car on credit at Maybank Finance?

3. Does service quality influence the car brand image on credit at Maybank Finance?

4. Does promotion influence the car brand image on credit at Maybank Finance?

5. Does brand image influence the decision to purchase a car on credit at Maybank Finance?

6. Does brand image mediate the influence of service quality on the decision to purchase a car on credit at Maybank Finance?

7. Does brand image mediate the influence of promotion on the decision to purchase a car on credit at Maybank Finance?

Fig 1. Research Model

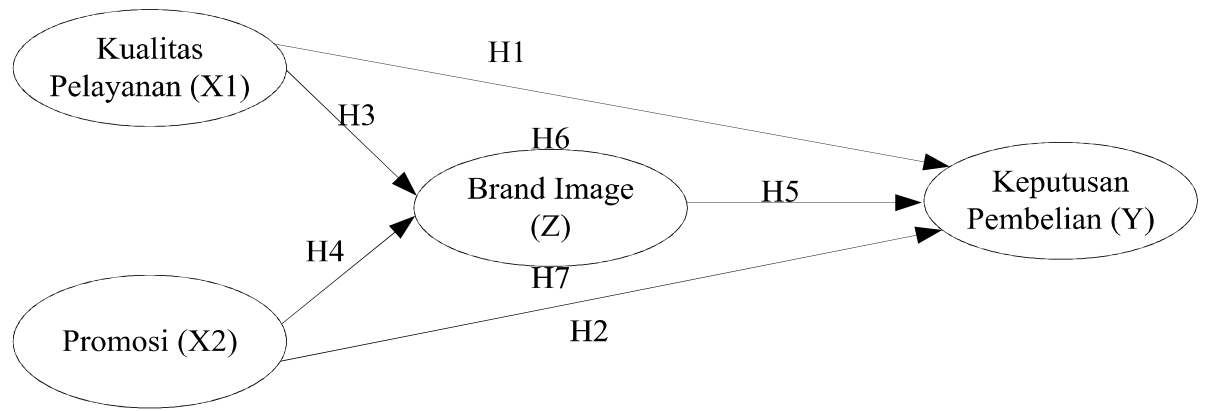

H1: Service quality has a positive effect on purchasing decisions for Maybank Finance credit products.

H2: Promotion has a positive effect on purchasing decisions for Maybank Finance credit products.

H3: Service quality has a positive effect on the brand image of Maybank Finance's credit products.

H4: Promotion has a positive effect on the brand image of Maybank Finance's credit products.

H5: Brand image has a positive effect on purchasing decisions for Maybank Finance credit products.

H6: Brand image positively mediates service quality on purchasing decisions for Maybank Finance credit products.

H7: Brand image mediates positive promotion on Maybank Finance's credit product purchase decision.

\section{METHODS}

The subjects in this study came from distributing questionnaires directly to people in DKI Jakarta and Tangerang who had purchased car loan financing products through Maybank Finance, where the results of the data were collected and processed by the researchers themselves. The reason for choosing this location is because the location is considered to have many respondents who have purchased car loan financing products. In this study, the number of samples was 100 people who came from Maybank Finance consumers. The data analysis technique in this study used Partial Least Square (PLS). There are three stages of analysis that can be used in PLS-SEM, namely:

1. The first stage, by analyzing the measurement model (outer model), namely the measurement model that connects the manifest (indicator) with its latent variables (Ghozali \& Latan, 2015). The measurement model with reflective indicators uses a validity and reliability test approach.

2. The second stage, by analyzing the structural model (inner model), namely the structural model that connects the latent variables, using two measurements, namely: R-Square (coefficient of determination), Q-Square (prediction relevance), f-Square (effect size) and Goodness of Fit Index (GoF).

3. The third stage, by testing the hypothesis.

\section{RESEARCH AND DISCUSSION}

\section{Test of Outer Model (Reliability and Validity)}

The tests analyzed the outer model, namely convergent validity, composite reliability, average variance extracted (AVE), and Cronbach's alpha. Outer model analysis shows that each indicator is related to its latent variable. The following is a picture of 2 construct models from this research that have been processed through SEM PLS. 
Fig 2. Construct

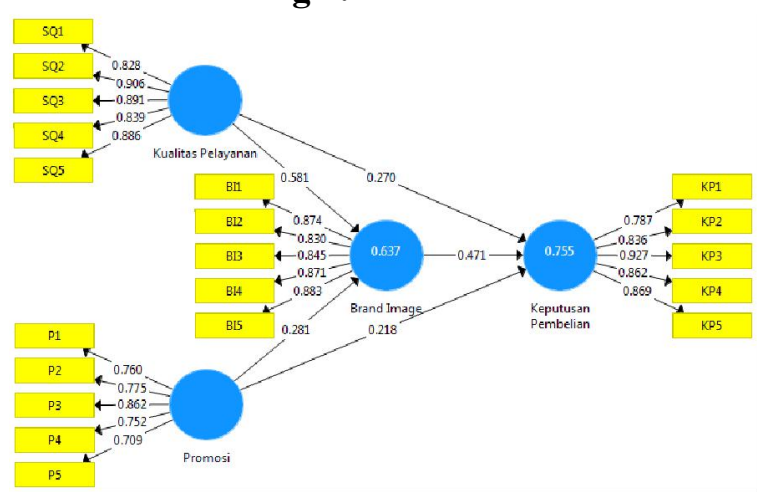

Based on the constructed model in Figure 2, the results of the validity test are described in the table below:

Table 2. Loading Factor

\begin{tabular}{|c|c|c|}
\hline Variable & Item & Loading Value \\
\hline \multirow{3}{*}{ Service Quality (X1) } & SQ1 & 0,828 \\
\cline { 2 - 3 } & SQ2 & 0,906 \\
\cline { 2 - 3 } & SQ3 & 0,891 \\
\cline { 2 - 3 } & SQ4 & 0,839 \\
\cline { 2 - 3 } & SQ5 & 0,886 \\
\cline { 2 - 3 } & P1 & 0,760 \\
\cline { 2 - 3 } & P2 & 0,775 \\
\cline { 2 - 3 } & P3 & 0,862 \\
\cline { 2 - 3 } & P4 & 0,752 \\
\cline { 2 - 3 } & P5 & 0,709 \\
\cline { 2 - 3 } & BI1 & 0,874 \\
\cline { 2 - 3 } & BI2 & 0,830 \\
\cline { 2 - 3 } & BI3 & 0,845 \\
\cline { 2 - 3 } & BI4 & 0,871 \\
\cline { 2 - 3 } & BI5 & 0,883 \\
\cline { 2 - 3 } & KP1 & 0,787 \\
\cline { 2 - 3 } & KP2 & 0,836 \\
\cline { 2 - 3 } & KP3 & 0,927 \\
\cline { 2 - 3 } & KP4 & 0,862 \\
\cline { 2 - 3 } & KP5 & 0,869 \\
\hline
\end{tabular}

The data in the table above shows convergent validity as seen from the loading factor value for each indicator. According to Hair et al. (2017), the loading factor parameter with $>0.7$ is considered to meet the convergent validity requirements. The research data above shows that the loading factor has a value above 0.7. So it can be said that the research data is said to be valid.

Table 3. Cross Loading

\begin{tabular}{|c|c|c|c|c|}
\hline Item & Service Quality & Promotion & Brand Image & $\begin{array}{c}\text { Purchasing } \\
\text { Decision }\end{array}$ \\
\hline SQ1 & 0,828 & 0,603 & 0,657 & 0,646 \\
\hline SQ2 & 0,906 & 0,623 & 0,688 & 0,661 \\
\hline SQ3 & 0,891 & 0,561 & 0,607 & 0,634 \\
\hline SQ4 & 0,839 & 0,590 & 0,751 & 0,800 \\
\hline SQ5 & 0,886 & 0,564 & 0,624 & 0,620 \\
\hline P1 & 0,452 & 0,760 & 0,547 & 0,474 \\
\hline P2 & 0,439 & 0,775 & 0,522 & 0,461 \\
\hline P3 & 0,580 & 0,862 & 0,602 & 0,651 \\
\hline P4 & 0,598 & 0,752 & 0,472 & 0,605 \\
\hline P5 & 0,537 & 0,709 & 0,455 & 0,563 \\
\hline BI1 & 0,562 & 0,505 & 0,874 & 0,650 \\
\hline BI2 & 0,504 & 0,444 & 0,830 & 0,548 \\
\hline BI3 & 0,688 & 0,659 & 0,845 & 0,735 \\
\hline BI4 & 0,733 & 0,577 & 0,871 & 0,742 \\
\hline
\end{tabular}




\begin{tabular}{|c|c|c|c|c|}
\hline BI5 & 0,766 & 0,664 & 0,883 & 0,818 \\
\hline KP1 & 0,585 & 0,634 & 0,705 & 0,787 \\
\hline KP2 & 0,598 & 0,595 & 0,686 & 0,836 \\
\hline KP3 & 0,734 & 0,661 & 0,745 & 0,927 \\
\hline KP4 & 0,681 & 0,647 & 0,676 & 0,862 \\
\hline KP5 & 0,736 & 0,539 & 0,725 & 0,869 \\
\hline
\end{tabular}

From the data above, the discriminant validity test is carried out by looking at the cross-loading value. This cross-loading value of each construct is evaluated to ensure that the correlation of the construct with the measurement item is more significant than the other constructs. It can be seen that the cross-loading value greater than 0.7 can be said to be valid, and the research data can be said to be valid.

Table 4. Discriminant Validity

\begin{tabular}{|l|c|l|l|c|}
\hline & Brand Image & $\begin{array}{l}\text { Purchasing } \\
\text { Decision }\end{array}$ & $\begin{array}{l}\text { Service } \\
\text { Quality }\end{array}$ & Promotion \\
\hline Brand Image & 0,861 & & & \\
\hline Purchasing Decision & 0,825 & 0,857 & & \\
\hline Service Quality & 0,771 & 0,780 & 0,871 & \\
\hline Promotion & 0,674 & 0,718 & 0,678 & 0,773 \\
\hline
\end{tabular}

The results show that the discriminant validity test is also carried out by looking at the discriminant validity value. The value of discriminant validity in this study is seen from the value of the Average Variance Extracted (AVE) root parameter and the correlation of the latent variable with the Average Variance Extracted (AVE) root $>$ the correlation of the latent variable. Furthermore, the second is seen from the crossloading parameter value $>0.7$; then, by fulfilling these conditions, it will be declared that the research is valid.

Table 5. Average Variance Extracted (AVE)

\begin{tabular}{|l|c|}
\hline \multicolumn{1}{|c|}{ Variable } & AVE \\
\hline Service Quality & 0,758 \\
\hline Promotion & 0,598 \\
\hline Brand Image & 0,741 \\
\hline Purchasing Decision & 0,735 \\
\hline
\end{tabular}

This study obtained the Average Variance Extracted (AVE) value of all variables above 0.5, shown in table 5. This means that the research conducted has met the requirements of the convergent validity test. According to Ghozali and Latan (2015), this is following the opinion that Convergent validity of a construct with reflective indicators evaluated with the Average Variance Extracted (AVE) value should be equal to 0.5 or more.Testing the reliability of the instrument using the coefficient value of composite reliability and Cronbach's Alpha. An instrument is declared reliable if Cronbach's Alpha value is $>0.7$, then it can be concluded that it is reliable. The reliability test in this study used Composite Reliability and Cronbach's Alpha, showing the following results:

\section{Composite Reliability}

The reliability test was carried out by looking at the composite reliability value. The results of composite reliability are said to be reliable if they have a value above 0.7 . The following is the composite reliability value.

Table 6. Composite Reliability

\begin{tabular}{|l|c|}
\hline & Composite Reliability \\
\hline Service Quality & 0,940 \\
\hline Promotion & 0,881 \\
\hline Brand Image & 0,935 \\
\hline Purchasing Decision & 0,933 \\
\hline
\end{tabular}

From the research above, it was found that the composite reliability value above concluded that the variables carried out by the study were said to be reliable with composite reliability above 0.7 , so they were considered to have good reliability (Ghozali \& Latan, 2015). It can be seen that the composite reliability value is above 0.7 , so all variables in this study are said to be reliable. 


\section{Cronbach's Alpha}

The reliability test is also strengthened with Cronbach's Alpha with the recommended value above 0.7 .

Table 7. Cronbach's Alpha

\begin{tabular}{|l|c|}
\hline & Cronbach's Alpha \\
\hline Service Quality & 0,920 \\
\hline Promotion & 0,830 \\
\hline Brand Image & 0,913 \\
\hline Purchasing Decision & 0,909 \\
\hline
\end{tabular}

The table above shows that the value of Cronbach's Alpha is that all constructs are above 0.7, which means that it meets the recommended value. The results of all reliability tests through composite reliability and Cronbach's alpha show that all indicators are reliable.

\section{Test of Inner Model (Structural Model Analysis)}

The inner model test is used to show whether there is a relationship or estimation strength between latent variables or constructs. The internal model analysis uses two ways, with R-square and Q-square. The $\mathrm{R}$-square test was used to test the value of the independent variable on the dependent variable. Evaluation of the model's predictive ability was carried out using R-square, giving criteria for R-square values of 0.67 (strong), 0.33 (moderate), and 0.19 (weak) (Jogianto \& Abdilah, 2009).

Table 8. R-square Coefficient

\begin{tabular}{|l|c|}
\hline \multicolumn{1}{|c|}{ Variable } & $R$-square \\
\hline Brand Image (M) & 0,637 \\
\hline Purchasing Intention (Y) & 0,755 \\
\hline
\end{tabular}

The table shows the R-square value. The table shows the value of R-square brand image $(\mathrm{M})=0.637=$ $63.7 \%$; the service quality and promotion variables together affect the brand image variable by $63.7 \%$, and the remaining $36.3 \%$ is influenced by the variable others not investigated. While the R-square value of purchasing decisions is $0.755=75.5 \%$, the variables of service quality, promotion, and brand image affect the purchasing decision variables by $75.5 \%$, and the remaining $24.5 \%$ is influenced by other variables not examined.After seeing the R-square value, the internal model analysis can be done by calculating the Qsquare value. The results of the calculation of the Q-square formula obtained a value of 0.911 or $91.1 \%$. Thus, the data of this study explained as much as $91.1 \%$, and the remaining $8.9 \%$ were other factors that were not related to the research conducted.

\section{Hypothesis Testing}

Hypothesis testing using path analysis (path analysis) using SEM PLS. Significance testing is carried out to determine the significance of direct and indirect effects, where the T-statistics requirement must be greater than the T-value. T-value used is 1.96 .

Table 9. Path Coefficient - Direct Effect

\begin{tabular}{|l|c|c|c|c|c|}
\hline & $\begin{array}{c}\text { Original } \\
\text { Sample (O) }\end{array}$ & $\begin{array}{c}\text { Sample } \\
\text { Mean (M) }\end{array}$ & $\begin{array}{c}\text { Standard } \\
\text { Deviation } \\
\text { (STDEV) }\end{array}$ & t -Statistic & P Values \\
\hline Service Quality $\rightarrow$ Purchasing Decision & 0.270 & 0.266 & 0.106 & 2.537 & 0.011 \\
\hline Promotion $\rightarrow$ Purchasing Decision & 0.2818 & 0.226 & 0.079 & 2.774 & 0.006 \\
\hline Service Quality $\rightarrow$ Brand Image & 0.581 & 0.586 & 0.095 & 6.079 & 0.000 \\
\hline Promotion $\rightarrow$ Brand Image & 0.281 & 0.282 & 0.099 & 2.847 & 0.005 \\
\hline Brand Image $\rightarrow$ Purchasing Decision & 0.471 & 0.470 & 0.091 & 5.150 & 0.000 \\
\hline
\end{tabular}

Hypothesis measurement can make comparisons between t-table and t-statistic values. The probability value, the p-value with $5 \%$ alpha, is $<0.05$, with a t-table value of $5 \%$ alpha is 1.96 . If the t-statistic value is higher than the t-table value, it means that the hypothesis is accepted, and vice versa if the t-statistic value is lower than the t-table, meaning that the hypothesis is rejected. This study tested four existing hypotheses, as follows:The first hypothesis test tested the influence of service quality on the decision to purchase a car on credit at Maybank Finance, with the following hypothesis:

H0: Service quality does not influence purchasing decisions 
H1: Service quality has a positive and significant influence on purchasing decisions.

Based on the table, the service quality variable has a positive and significant effect on the purchasing decision variable with a t-statistic of $2.537>1.96$, with a significance value of $0.011<0.05$. Thus H0 is rejected, and $\mathrm{H} 1$ is accepted. So the first hypothesis is accepted, meaning that service quality has a positive and significant influence on purchasing decisions. This means that if the quality of service provided is good, it will increase the decision to purchase a car on credit at Maybank Finance.The second hypothesis test tested the influence of promotion on the decision to purchase a car on credit at Maybank Finance, with the following hypothesis:

H0: Promotion does not affect purchasing decisions.

H2: Promotion has a positive and significant influence on purchasing decisions

Based on the table, the promotion variable affects the purchasing decision variable with a t-statistic of $2.774>1.96$, with a significance value of $0.006<0.05$. Thus H0 is rejected, and H2 is accepted. So the second hypothesis is accepted, meaning that promotion has a positive and significant influence on purchasing decisions. This means that if the promotion increases, it will increase the decision to purchase a car on credit at Maybank Finance.The third hypothesis test tests the influence of service quality on Maybank Finance's brand image, with the following hypothesis:

H0: Service quality does not affect brand image

H3: service quality has a positive and significant effect on brand image.

Based on the table, the service quality variable has a positive and significant effect on the brand image variable with a t-statistic of $6.079>1.96$, with a significance value of $0.005<0.05$. Thus H0 is rejected, and $\mathrm{H} 3$ is accepted. So the third hypothesis is accepted, meaning that service quality has a positive and significant influence on brand image. This means that if the quality of service increases, it will lead to an increase in the brand image of Maybank Finance.The fourth hypothesis test tests the influence of promotion on Maybank Finance's brand image, with the following hypothesis:

H0: Promotion does not affect brand image.

H4: promotion has a positive and significant impact on brand image.

Based on the table, the promotion variable influences the brand image variable with a t-statistic of $2.847>1.96$, with a significance value of $0.005<0.05$. Thus $\mathrm{H} 0$ is rejected, and H4 is accepted. So the fourth hypothesis is accepted, meaning that promotion has a positive and significant influence on brand image. This means that if promotions increase, it will affect Maybank Finance's brand image.The fifth hypothesis test tested the influence of brand image on the decision to purchase a car on credit at Maybank Finance, with the following hypothesis:

H0: brand image does not influence purchasing decisions.

H5: brand image has a positive and significant influence on purchasing decisions.

Based on the table, the brand image variable influences the purchasing decision variable with a tstatistic of $5.150>1.96$, with a significance value of $0.000<0.05$. Thus H0 is rejected, and H5 is accepted. So the fifth hypothesis is accepted, meaning that brand image has a positive and significant influence on the decision to return. This means that if the brand image increases, it will affect purchasing a car on credit at Maybank Finance.

Table 10. Test of Mediating Variable

\begin{tabular}{|l|c|c|c|c|c|}
\hline & $\begin{array}{c}\text { Original } \\
\text { Sample (O) }\end{array}$ & $\begin{array}{c}\text { Sample } \\
\text { Mean (M) }\end{array}$ & $\begin{array}{c}\text { Standard } \\
\text { Deviation } \\
\text { (STDEV) }\end{array}$ & t-Statistic & P Values \\
\hline $\begin{array}{l}\text { Service Quality } \rightarrow \text { Brand Image } \rightarrow \\
\text { Purchasing Decision }\end{array}$ & 0.273 & 0.277 & 0.077 & 3.557 & 0.000 \\
\hline $\begin{array}{l}\text { Promotion } \rightarrow \text { Brand Image } \rightarrow \text { Purchasing } \\
\text { Decision }\end{array}$ & 0.132 & 0.130 & 0.049 & 2.686 & 0.007 \\
\hline
\end{tabular}

The sixth hypothesis test examines the role of brand image in mediating the effect of service quality on car purchase decisions on credit at Maybank Finance, with the following hypothesis:

$\mathrm{H} 0$ : brand image is not able to mediate the effect of service quality on purchasing decisions. 
H6: brand image can mediate the effect of service quality on purchasing decisions.

Based on the table, the brand image variable can mediate the effect of service quality on the purchasing decision variable with a t-statistic of $3.557>1.96$, with a significance value of $0.000<0.05$. Thus $\mathrm{H} 0$ is rejected, and $\mathrm{H} 6$ is accepted. So the sixth hypothesis is accepted, meaning that brand image mediates the effect of promotion on the decision to return. This means that if the quality of service provided is getting better, it will form a good brand image in the minds of consumers, then this will further increase the decision to buy a car on credit at Maybank Finance.The seventh hypothesis test tested the role of brand image in mediating the effect of promotion on the decision to purchase a car on credit at Maybank Finance, with the following hypothesis:

$\mathrm{H} 0$ : brand image is not able to mediate the effect of promotion on purchasing decisions.

$\mathrm{H} 7$ : brand image can mediate the effect of promotion on purchasing decisions.

Based on the table, the brand image variable can mediate the effect of promotion on the purchasing decision variable with a t-statistic of $2.686>1.96$, with a significance value of $0.007<0.05$. Thus $\mathrm{H} 0$ is rejected, and H7 is accepted. So the sixth hypothesis is accepted, meaning that brand image mediates the effect of promotion on the decision to return. This means that if the promotion increases, it will cause the company's brand image to increase, which will impact the decision to purchase a car on credit at Maybank Finance.

\section{CONCLUSION}

Based on the research conducted, the conclusions obtained are as follows:

1. Service quality has a positive and significant influence on purchasing decisions. So it can be said, good service quality will affect the decision to buy a car on credit at Maybank Finance.

2. Promotion has a positive and significant influence on purchasing decisions. So it can be said that the company's promotions will influence the decision to purchase a car on credit at Maybank Finance.

3. Service quality has a positive and significant impact on brand image. So it can be said, good service quality will form a good brand image in the minds of consumers.

4. Promotion has a positive and significant impact on brand image. So it can be said, promotions are increasing, then this will affect the company's brand image

5. Brand image has a positive and significant influence on purchasing decisions. So it can be said, a good brand image will influence the decision to buy a car on credit at Maybank Finance.

6. Brand image can mediate the influence of service quality on purchasing decisions. So it can be said, if the quality of service provided is getting better, it will form a good brand image in the minds of consumers, then this will further increase the decision to purchase a car on credit at Maybank Finance.

7. Brand image can mediate the effect of promotion on purchasing decisions. So it can be said, This means that if the promotion is increasing, it will cause the company's brand image to increase, then this will have an impact on the decision to buy a car on credit at Maybank Finance.

The following are theoretical suggestions given based on research that has been done, namely:

1. The results of this study are further developed to find out what factors can influence the decision to purchase a car on credit at Maybank finance

2. For further researchers interested in researching the factors that influence purchasing decisions, it is better to connect with other variables that may have an effect that has not been examined in this study.

3. The population of this study is all consumers in DKI Jakarta and Tangerang who have purchased a car on credit through Maybank Finance. It is hoped that further researchers can expand the coverage area in population collection, and it is also recommended to increase the number of samples in the study so that it is more representative of the actual situation.

4. This research was conducted during the covid-19 pandemic, where it was impossible to have face-toface meetings with respondents so that researchers distributed questionnaires via Google Form. It is recommended for further researchers to be able to conduct research face-to-face directly to prospective respondents in filling out questionnaires so that the results obtained are more accurate.

The practical advice given is based on research done, namely for Maybank Finance, to maintain service quality because it is very influential on purchasing decisions. If the service factor continues to be 
improved, the level of service purchasing decisions can inevitably increase very well. Second, Maybank Finance is expected to continue to improve and maintain the company's brand image of the products/services provided because the brand image has proven to be able to become a benchmark for consumers to make purchasing decisions with more aggressive promotions, so that people are more getting to know Maybank finance, giving a positive impression so that customers remember the brand by providing advantages possessed by the company that is not found in other similar companies such as company facilities, affordable prices, to increase service users. Third, Maybank finance is expected to produce advertisements and provide more attractive promotional activities. The frequency of advertising needs to be increased, and the timing of promotional activities needs to be better structured to be effective. The author's suggestion is to provide attractive cashback promos for consumers interested in making purchases at Maybank Finance.

\section{REFERENCES}

[1] Abiyoso, Srikandi Kumadji dan Andriani Kusumawati (2017) Pengaruh Kualitas Layanan Terhadap Citra Perusahaan Dan Loyalitas Pelanggan (Survei Pada Pelanggan PT Kereta Api Indonesia Daerah Operasi 8 Surabaya Gubeng yang Menggunakan Kereta Eksekutif "Bangunkarta" dengan Tujuan Surabaya Gubeng menuju Jakarta Gambir). Jurnal Administrasi Bisnis. 50 (4), 64-70

[2] Ali, Hapzi, Evi Narulita dan Adi Nurmahdi (2018) The Influence of Service Quality, Brand Image and Promotion on Purchase Decision at MCU Eka Hospital. Saudi Journal of Business and Management Studies (SJBMS) . 3 (1), 88-97

[3] Alma, Buchari., (2016) Manajemen Pemasaran dan Pemasaran Jasa. Bandung: Alfabeta

[4] Amitay, Y., Winoto Tj, H., Saparso \& Wahyoedi, S. (2020). The Impact of Celebgram Endorsement on Purchase Intention: The Mediating Effect of Customer Attitude and Brand Awareness. 8th International Conference on Entrepreneurship and Business Management (ICEBM) UNTAR.

[5] Anggraini, Novita, Qodariah Barkah dan Titin Hartini (2020) Pengaruh Promosi, Harga, Kualitas Produk Terhadap Keputusan Pembelian Dengan Citra Merek Produk Rabbani Di Palembang. Jurnal Neraca. 4 (1), : 26- 40

[6] Armayani, Astari dan I Made Jatra (2019) Peran Brand Image Memediasi Promosi Dan Harga Terhadap Keputusan Pembelian Smartphone Samsung Di Kota Denpasar. E-Jurnal Manajemen. 8 (8), 5222-5239

[7] Assauri, Sofjan. (2013). Manajemen Pemasaran. Jakarta : Rajawali Pers

[8] Athar, Handry Sudiartha (2020) The Effect Of Brand Image, Price And Promotion On The Decision To Stay At Cadaka Hotel - Central Java. Open Journal Systems. 14 (12), 3603-3611

[9] Devina, Benedhita dan Asep Rokhyadi (2019) Pengaruh promosi dan kualitas pelayanan terhadap keputusan menggunakan jasa leasing yang dimediasi oleh kepuasan konsumen. Jurnal Manajemen. 11 (1), 56-64

[10] Fandy Tjiptono. (2015). Strategi Pemasaran. Edisi 4. Yogyakarta: Andi

[11] Farenzia, Siska dan Raymond (2020) Pengaruh Kualitas Pelayanan, Citra Merek Dan Promosi Terhadap Keputusan Pembelian Jasa Transportasi Online Grab. Jurnal Manajemen Bisnis. 33 (1), 1-14

[12] Ghozali, I dan Latan, H., (2015), Konsep, Teknik, Aplikasi Menggunakan SmartPLS 3.0 untuk Penelitian Empiris. BP Undip. Semarang.

[13] Hair, Joseph F., Black, W. C., Babin, B. J., \& Anderson, R. E. (2010). Multivariate Data Analysis (7 ${ }^{\text {th }}$ Ed). Englewood Cliffs: Prentice Hall.

[14] Harman Malau (2017) Manajemen Pemasaran: Teori dan Aplikasi Pemasaran Era Tradisional Sampai Era Modernisasi Global. Bandung: Alfabeta

[15] Hermiyenti, Suci dan Yunia Wardi (2019) A Literature Review on the Influence of Promotion, Price and Brand Image to Purchase Decision. Business and Management Research. volume 64. h. 538-545

[16] Juhaeri (2018). The Influence of Brand Image, Service Quality, Price Perception and Trust on the Purchase Decision of Welding Workshop Welding Www.Kanopirumah.Com. Pinisi Discretion Review. 2(1), 17- 24

[17] Khaerani, Rani Apri dan Apriatni Endang Prihatini. (2020). Pengaruh Promosi Dan Brand Image Terhadap Keputusan Pembelian Pada Layanan Traveloka. Jurnal Administrasi Bisnis. 9 (3), 310-317

[18] Kotler, Philip and Kevin Lane Keller, (2016). Marketing Managemen, 15th Edition, Pearson Education,Inc

[19] Kotler, Philip dan Gary Amstrong. (2018). Principles of Marketing. Edisi 15 Global Edition. Pearson

[20] Labesi, Sisca Claudya (2019) Pengaruh Brand Image Dan Kualitas Pelayanan Terhadap Keputusan Pembelian Mobil Pajero Pada PT. Makassar Mandiri Putra Utama. Jurnal EMBA. 7 (3), 3778 - 3787

[21] Lupiyoadi, Rambat. (2014). Manajemen Pemasaran Jasa Berbasis Kompetensi (Edisi 3). Jakarta: Salemba Empat. 
[22] Martina, Merllyn dan Arifin Sitio (2018) The Effect of The Quality of Service, Products \& Promotions on the Purchase Decision of Simpati Card \& It's Impact on the Satisfaction of Telkomsel Customers in Kupang City. International Journal of Science and Research. 7 (8), 477-485

[23] Mursid, M (2016) Manajemen Pemasaran. Jakarta: Bumi Aksara

[24] Pradita, Sylvia Okta dan Arifin Sitio (2020). The Impact Of Brand Image And Service Quality On Buying Decisions And Its Implication On Consumer Satisfaction. International Journal of Digital Business Managemen. 1 (3), 394-408

[25] Prayogi, Slamet dan Awan Santosa (2019) The Influence Of Product Quality, Prices And Promotions On Interest In Buying Sri Sulastri’s Batik. e-Jurnal Apresiasi Ekonomi . 7(1), 9 - 17

[26] Rizqi, M. Alfat Nur, Puji Lestari dan Ida Wiendijarti (2017) Pengaruh Kualitas Pelayanan Terhadap Citra Perusahaan Listrik Negara. Interact. 6 (2), 61-77

[27] Sampeliling, Alexander (2016) Pengaruh Kualitas Layanan Terhadap Keputusan Konsumen Dalam Pemilihan Perusahaan Jasa Pembiayaan Kredit (Studi Kasus Pada Pt Finansia Multi Finance Samarinda). Forum Ekonomi. 17 (2), 45-53

[28] Santikayasa, I Made Ari dan I Wayan Santika (2019) Peran Citra Toko Dalam Memediasi Pengaruh Kualitas Pelayanan Terhadapniat Beli Ulang Konsumen. E-Jurnal Manajemen. 8 (2), 8104 - 8134

[29] Saparso. (2018). Kinerja Asuransi Jiwa di Indonesia (Studi Atas Komitmen Nasabah), Ukrida Press, Jakarta.

[30] Saputra, I Made Deddy dan I Nyoman Nurcaya (2018) Pengaruh Kualitas Layanan Terhadap Loyalitas Nasabah Melalui Citra Perusahaan Sebagai Variabel Mediasi. E-Jurnal Manajemen. 7 (12), 6675 - 6702

[31] Sekaran, U., \& Bougie, R. (2016). Research Methods for Business: A Skill Building Approach, 7th Edition. United Kingdom: John Wiley

[32] Setiadi. (2013). Konsep dan praktek penulisan riset keperawatan (Ed.2) Yogyakarta: Graha Ilmu

[33] Situmorang, Irwanty L (2017) Pengaruh Kualitas Produk Dan Iklan Terhadap Citra Merek Dan Keputusan Pembelian Produk Kecantikan Merek Pond's Pada Remaja Di Kota Pekanbaru . Jurnal Online Mahasiswa. 4 (1), $72-86$

[34] Solimun et al. (2017). Metode Statistika Multivariat Pemodelan Persamaan Struktural (SEM) Pendekatan WarpPLS. Malang: UB Press.

[35] Sugiyono (2015). Metode Penelitian Kombinasi (Mix Methods). Bandung: Alfabeta.

[36] Supriyanto dan Ernawati (2010) Pemasaran Industri Jasa Kesehatan. Yogyakarta: Andi Offset

[37] Susanto, Himawan Wijarnako. (2016). Power Branding : Membangun Merek Unggul dan Organisasi Pendukungnya. Jakarta: Quantum Bisnis\&Manajemen

[38] Tjiptono, Fandy dan Greforius, Chandra. (2016). Pemasaran Jasa (Prinsip, Penerapan, dan Penelitian), Yogyakarta: Andi

[39] Wahyoedi, S., Saparso, S., Tecoalu, M., \& Winoto Tj, H. (2021). The Effect of Service Quality, Learning Quality, and Promotion Strategy on Parents' Decisions in Choosing ABC Primary Schools. Budapest International Research and Critics Institute (BIRCI-Journal): Humanities and Social Sciences, 4(1), 999-1005. https://doi.org/10.33258/birci.v4i1.1701

[40] Wahyoedi, Soegeng, and Hery Winoto. 2018. "Pengaruh Religitas, Kualitas Layanan Dan Trust Terhadap Loyalitas Nasabah Bank Syariah Di Kota Bogor.” Jurnal Riset Ekonomi Dan Manajemen 17 (2): 189. https://doi.org/10.17970/jrem.17.17 0204.id.

[41] Yolanda dan Dimas Firdaus, (2019) Pengaruh Kualitas Pelayanan Dan Promosi Terhadap Citra Perusahaan Serta Dampaknya Pada Keputusan Nasabah Menabung (Studi Kasus Pada Bank BRI Kantor Cabang Pembantu Meester). Jurnal Manajemen. 07 (1), 118 -140 